\title{
Motivation Employees of Sri Lanka Railways for Better Performances Through Concentration and Mindfulness In The Noble Eight Fold Path In Buddhism
}

\author{
Wijaya Samarasinghe \\ No.393/21, Dutugamunu MW, Thalangama North, \\ Thalangama, Sri Lanka
}

\begin{abstract}
According to Buddhism, It can be identified two objectives as long term and short term in Buddhist counselling related to the Employees. The long-term objective of counseling is to cessation of such suffering by attaining Nibbana. The main focus of this study is investigating how the Buddhist counseling can help employees to unload their work-related burden and create conducive environment for employment by studying whether employees could be motivated by the Concentration and Mindfulness in noble eightfold path in order to enhance its performances. Concentration and mindfulness is significantly important in employee counseling. In this study, it was studied whether concentration and mindfulness in noble eight-fold path could motivated employee counseling at the SLR as concentration is exclusive and settle down with one item while ignoring all others, whereas mindfulness in inclusive which focus of attention and watches with a broad area. Accordingly, Noble eight-fold -concentration and mindfulness in relation to the employee counseling was measured and the summary of the analysis of data it could be concluded that sixty one percent of employees were aware to practice concentration in their job-related matters and 39 percent of them were strangers to the importance of concentration and fifty eight percent of employees were aware of the importance of mindfulness in their job-related matters and $\mathbf{4 2}$ percent of them were strangers to the important of mindfulness. Therefore, it can be concluded that the employees of the SLR could be motivated by the Buddhist way of counseling to enhance their performances.
\end{abstract}

\section{INTRODUCTION}

In the definition of counseling it is included exclusive and inclusive counseling which goes along with talking therapies (Aldridg, 2014). Counseling covers various range of talking therapies (BACP,1978).

\section{Counseling in Buddhism}

Buddha had clear understanding about suffering arises in human mind due to craving, ignorance and hatred exist (Polgolle Kushaladhamma Thero, 2017). According to Buddhism, Buddhist counseling has two objectives that of long term and short term. The long-term objective of counseling is to cessation of such suffering by attaining Nibbana.

\section{Counselling Employees}

Counselling at the workplace comes as a remedy for organizational problems that related to personal and work-related problems face by the employees. There are various other reasons in addition to the stress which is required employee counselling in a work place, as mentioned in the study in details. According to Ajila and Adetayo (2013), employee counselling will help employees to overcome above issues. 


\section{Employee Counseling}

As organizations are made up with people and there will be no organizations with employees who do not have some sort of work related stresses among them. According to Kaila (2005), employee counseling helps employees to cope with all sort of problems either personal or work-related problems or conflicts. Employee counseling has become a major innovative tool that has been developed by the Human Resource (HR) practitioners in the corporate world to attract and retain quality workforce within organizations. Any organization could gain competitive advantages from employee counseling by retaining their employees within the organization to maintain the reputation and goodwill of the organization. The organization could monitor, assess and seek to improve poor performance of employees and address poor performance continuously through "personal counseling" to the employees (Kaila, 2005). According to Ekpang (2015), employee counseling is an act of assisting employees to have a positive perception about things such as work and personal life. It aims to assist employees to possibly perceive things from a different point of view from what the initially perceive it, to enable the employees function effectively. Counseling can enable employees to develop positive thinking, experiences and behaviors that would facilitate positive change.

\section{Counseling on Employee Problems, Conflicts and Performances}

It is a common situation that the reflection of low work performance from employees when they have interference forms their personal problem to their work-related issues. This situation is created as employees started thinking that employers are not interested in their (employees) personal issues and difficulties which will have an impact to employees to feel no sense of care or belongings towards the organization from their part and that impact to the productivity of the organization from its perspectives (Ajila nad Osunrinde 2015). According to them establishment of an employee counseling mechanism in the workplace for employees to discuss their personal issues is an issue related to corporate ethics and professionalism.

\section{Workplace Stress and Employee Counseling}

According to Matalo and Mukulu(2016), absenteeism and sicknesses are the most obvious effects of employee stresses from various other factors. Difficult in recruit and retaining good employees that are detrimental to organizational performance and profitability. When employees take off from work or keep absent for work due to various reasons, it will affect remaining employees as they will have to carry out additional works or tasks to cover up the duties of the employees who are absent.

\section{Noble Eightfold Path- Concentration and Mindfulness}

According to Thanissaro the eight-fold path is discussed under three main headings as discernment, virtue and concentration. Right view and right resolve comes under discernment, right speech, right action, and right livelihood comes under virtue and right effort, right mindfulness, and right concentration come under concentration. Here we discuss only mindfulness and concentration as relevant to our conceptualization. Mindfulness is a broader and larger function than the concentration which encompasses all functions. Concentration is exclusive and settling down with one item while ignoring all others, whereas mindfulness is inclusive which focuses on attention and watches with a broad area. Concentration is the ability to intentionally sustain situation and shift one's attention by controlling shift of attention including minimizing involuntary shifts of attention. Noble eight-fold -concentration in relation to the employee counseling was measured with 15 questions in appendix: 1 and mindfulness was measured with seventeen questions given in appendix 2 .

According to the summary of the analysis of data related to the concentration and mindfulness in relation to the noble eight-fold, it was found that sixty one percent of employees were aware 
to practice concentration in their job related matters and 39 percent of them were strangers on the importance of concentration and fifty eight percent of employees were aware of the importance of mindfulness in their job related matters and 42 percent of them were strangers to the importance of mindfulness. Therefore, it can be concluded that the employees can be motivated by the Buddhist way of counseling to enhance their performances.

\section{References}

Aldridge Sally, A short Introduction to Counseling, SAGE Publication,2014

Ajila, C. O., \& Adetayo, H. O. (2013. Workplace Counselling: Implications for Enhanced Productivity. IFE Psychologia, 21(3), 197-210.

Ajala E.M., Osunrinde, T.P(2015), . The Effects of Employee Asistance Progames on Workers' Perfromance in Selected Work Organizations in Ondo and Edo States, Nigeria. 1-15

British Association for Counselling, Standing Conference for the Advancement of Counselling,1978

Ekpang, Pauline U(2015), Counselling For Effective Work Performance: A Way for Service Improvement, IOSR Journal of Humanities And Social Science, Vol. 20, Issue 3, 39-43

Kaila, H.L. (2005). Human Resource Management. Delhi: Kalpaz Publications. p. 254

Matalo Roose Syombua and Mukulu, Elegwa, Role of Counseling in Employee Performance in Public Universities, International Journal of Humanities and Social Science, Vol6, No.8. 2016. p. 232.

Nyasha, Mapira, Tendai, Chazuza, Makaita Mlingwa Margret, asiyana Taguma, Pension Katsuro, Edward Negwaiya, Fariepi Mugozhi, Vhuramayi Chimbisdi and Bigboy, Mapira(2013), The Role of Counseling in Changing Employee Behavior: A Case Study of Bulawayo Premier Service Medical Aid Society in Zimbawe. Journal of Social Sciences,

Polgolle Kusaladhamma Thero(2017), The Buddhist Counseling Psychology, Available in www. Buddhanet./PDF, Retrieved on 24.07.17, p. 1

Thanissaro Bhikkhu, The Noble Eightfold Path 13 Meditation Talks, Published by Metta Forest Monastery Valley Center, CA 92082-1409 U.S.A. 